\title{
Association of interleukin 23 receptor gene with sarcoidosis
}

\author{
Hyun Soo Kim ${ }^{\mathrm{a}}$, Dongseok Choi ${ }^{\mathrm{b}}$, Lyndell L. Lim ${ }^{\mathrm{c}}$, Gopal Allada ${ }^{\mathrm{d}}$, Justine R. Smith ${ }^{\mathrm{e}}$, \\ Carrie R. Austin ${ }^{\mathrm{e}}$, Trudy M. Doyle ${ }^{\mathrm{e}}$, Kelley A. Goodwin ${ }^{\mathrm{e}}$, James T. Rosenbaum ${ }^{\mathrm{e}}$ and \\ Tammy M. Martin ${ }^{\mathrm{e}, *}$ \\ ${ }^{a}$ Department of Laboratory Medicine, Hallym University College of Medicine, Seoul, Korea \\ ${ }^{\mathrm{b}}$ Division of Biostatistics, Department of Public Health \& Preventive Medicine, Oregon Health \& Science \\ University, Portland, OR, USA \\ ${ }^{\mathrm{C}}$ Centre for Eye Research Australia, University of Melbourne, Royal Victorian Eye and Ear Hospital, East \\ Melbourne, VIC, Australia \\ ${ }^{\mathrm{d}}$ Pulmonology and Critical Care Medicine, Oregon Health \& Science University, Portland, OR, USA \\ ${ }^{\mathrm{e}}$ Department of Ophthalmology, Casey Eye Institute, Oregon Health \& Science University, Portland, OR, USA
}

\begin{abstract}
Interleukin 23 receptor $(I L 23 R)$ gene has been reported as a genetic factor strongly associated with inflammatory bowel disease, psoriasis, and ankylosing spondylitis. We investigated the association between $I L 23 R$ gene single nucleotide polymorphisms (SNPs) and susceptibility to sarcoidosis, including the clinical manifestation of uveitis.

Ninety-one sarcoidosis subjects (58 with and 33 without uveitis) and 104 healthy controls were genotyped for eleven $I L 23 R$ SNPs. DNA was amplified using specific PCR primers and genotyped by denaturing HPLC and/or direct DNA sequencing. Case-control frequency comparisons were analyzed using Chi square test.

Three IL23R SNPs, rs7517847 (intron 6), rs11465804 (intron 8), and rs11209026 (exon 9, c.1142G>A, p.Arg381Gln) were associated with sarcoidosis in our population $(p<0.05)$ : rs7517847 showed increased frequencies in sarcoidosis compared to controls, but rs11465804 and rs11209026 were decreased. Two of these SNPs were associated with the uveitis subgroup compared to controls: rs11465804 (0.9\% vs. $7.2 \%, \mathrm{OR}=0.11, \mathrm{P}=0.013)$ and $\mathrm{rs} 11209026(1.8 \%$ vs. $7.3 \%, \mathrm{OR}=0.23, \mathrm{P}=$ 0.038).

This finding indicates the association of $I L 23 R$ polymorphism with sarcoidosis, especially with sarcoid uveitis. IL23R may be a common susceptibility gene shared by several autoimmune disorders including inflammatory bowel disease, psoriasis, and ankylosing spondylitis and sarcoid uveitis.
\end{abstract}

Keywords: Interleukin 23 receptor, polymorphism, sarcoidosis, uveitis

\section{Introduction}

Sarcoidosis is a systemic inflammatory disease characterized by non-caseating granulomatous inflammation. It frequently presents with bilateral hilar adenopathy, pulmonary infiltration, ocular and skin lesions, but liver, spleen, lymph node, salivary gland, heart, nervous system, muscles, bones and other organs may also be involved. About $11-83 \%$ of patients with sarcoidosis

${ }^{*}$ Corresponding author: Tammy M. Martin, Department of Ophthalmology, Casey Eye Institute, Oregon Health \& Science, University, 3181 SW Sam Jackson Park Road, Portland, OR 97239, USA. Tel.: +1 503494 3372; Fax: +1 503494 6875; E-mail: martint@ ohsu.edu. have ocular involvement and uveitis is the most common of all sarcoid eye lesions [1].

The etiology of sarcoidosis still remains unknown. Sarcoidosis is thought to be a complex multifactorial disease resulting from interaction of multiple genes and environmental factors. Familial aggregation and racial differences in incidence suggest the existence of genetic susceptibility to sarcoidosis [2]. Although some HLA genes and other candidate genes such as various cytokine genes, receptor genes and others have been reported to show an association with sarcoidosis, many of the reported associations have not been replicated [35].

Interleukin 23 receptor (IL23R) gene on chromosome $1 \mathrm{p} 31$ was identified as a susceptibility gene for 
Table 1

Demographic data of control and sarcoidosis subjects with and without uveitis

\begin{tabular}{|c|c|c|c|c|}
\hline & $\begin{array}{c}\text { Sarcoidosis } \\
\text { total } \\
n=91\end{array}$ & $\begin{array}{c}\text { Sarcoidosis } \\
\text { with uveitis } \\
n=58\end{array}$ & $\begin{array}{c}\text { Sarcoidosis } \\
\text { without uveitis } \\
n=33\end{array}$ & $\begin{array}{c}\text { Control } \\
n=104\end{array}$ \\
\hline Age $($ mean $\pm \mathrm{SD})$ & $58.2 \pm 12.2$ & $56.3 \pm 6.7$ & $57.5 \pm 10.5$ & $48.4 \pm 11.9$ \\
\hline Sex (\% men: women) & 30: 70 & 33: 67 & $24: 76$ & $42: 58$ \\
\hline \multicolumn{5}{|l|}{ Ethnicity/Race* } \\
\hline Caucasian & $83(91.2 \%)$ & $49(84.5 \%)$ & $32(97.0 \%)$ & $96(92.3 \%)$ \\
\hline African-American & 5 & 4 & 1 & \\
\hline Native American & & & & 1 \\
\hline Asian & 2 & 2 & & 2 \\
\hline Middle Eastern & 1 & 1 & & \\
\hline Mixed racial groups & & & & 5 \\
\hline Biopsy proven cases & $52(57.1 \%)$ & $30(51.7 \%)$ & $22(66.7 \%)$ & \\
\hline
\end{tabular}

*As categorized based on self-report.

inflammatory bowel disease in the North American genome-wide association study [6]. Subsequent studies in several populations revealed the association between these $I L 23 R$ polymorphisms and inflammatory bowel disease (IBD), psoriasis, ankylosing spondylitis, and idiopathic achalasia [7-9]. We have also found an independent association of the IL23R gene with acute anterior uveitis (unpublished data). Hence, $I L 23 R$ gene might be a common genetic factor for inflammatory bowel disease and other chronic inflammatory autoimmune diseases.

IL23 is a heterodimeric regulatory cytokine consisting of a p19 and a p40 subunit produced by activated macrophages and dendritic cells. IL23 activity is mediated by binding to the IL23 receptor complex which is composed of an IL- $12 \mathrm{R} \beta 1$ subunit and a unique cytokine receptor subunit termed IL23R [10]. IL23 binding with IL23R on Th17 cell serves to expand differentiated Th17 cell population and IL23-Th17 interactions are thought to play an important role in the development of autoimmune inflammatory disorders [11].

We investigated the association of $I L 23 R$ polymorphisms with sarcoidosis and especially with sarcoid uveitis. We selected the $I L 23 R$ gene as a candidate gene in sarcoidosis because $I L 23 R$ gene was reported to be a susceptibility gene for Crohn's disease, which is characterized by non-caseating granulomas, a feature also found in sarcoidosis.

\section{Materials and methods}

\subsection{Study subjects}

Ninety-one sarcoidosis subjects and 104 healthy controls were included in the study. Written informed consent was obtained from all subjects and the study was performed under a protocol approved by the Institutional Review Boards of Oregon Health \& Science University.

The validation of a sarcoidosis diagnosis was made on the basis of the International Consensus Statement on Sarcoidosis [1,12]. All subjects were interviewed about the course of their disease and agreed to release relevant medical records for research review. Three doctors who were blinded from the genetic analysis reports (one ophthalmologist, one pulmonology specialist and one pathologist) reviewed all the subjects' medical records. Fifty two cases $(57.1 \%)$ were confirmed by tissue biopsy and remaining cases without histological confirmation had radiographic evidence of pulmonary sarcoidosis (bilateral hilar adenopathy, etc) and clinical presentation compatible with sarcoidosis. Among the ninety-one sarcoidosis subjects, $64(70.3 \%)$ were women and $58(63.7 \%)$ presented with uveitis. The majority of the participants in this study were Caucasian (91.2\% of cases, $92.3 \%$ of controls). The ethnicity of non-Caucasians were 5 African-Americans, 2 Asians, and 1 middle Eastern in sarcoidosis group, whereas 1 native American, 2 Asians, and 5 mixed races in control group. Details of these patients and controls are listed in Table 1.

\subsection{Genotyping}

The eleven SNPs of IL23R gene (rs1004819, rs7517847, rs7530511, rs10489629, rs2201841, rs11465804, rs11209026, rs1343151, rs10889677, rs11209032, and rs1495965) were selected on the basis of their previously reported association with IBD and psoriasis susceptibility [6]. Genomic DNA was extracted from peripheral blood samples of all subjects. Regions of the $I L 23 R$ gene flanking the specific SNP locations were amplified using specific primers and a 
Table 2

List of each SNP of IL23R, the genotyping methods, and primers used in this study

\begin{tabular}{|c|c|c|c|c|c|c|}
\hline SNP & Location & $\begin{array}{c}\text { Chromosome } \\
\text { position }\end{array}$ & Alleles & $\begin{array}{l}\text { Amino acid } \\
\text { substitution }\end{array}$ & Genotyping methods & $\begin{array}{l}\text { Primer used } \\
\text { (F, forward; R, reverse) }\end{array}$ \\
\hline rs 1004819 & Intron 5 & 67442801 & G/A & - & PCR-dHPLC/sequencing & $\begin{array}{l}\text { F: agatctggtggaaatatgtgaaacct } \\
\text { R: agttcggcttggccactgttat }\end{array}$ \\
\hline rs7530511 & Exon 7 & 67457975 & $\mathrm{C} / \mathrm{T}$ & Pro310Leu & PCR-dHPLC/sequencing & $\begin{array}{l}\text { F: gtctagaagacagcttgg } \\
\text { R: agccactgtgctcagcagaaa }\end{array}$ \\
\hline rs2201841 & Intron 7 & 67466790 & $\mathrm{~A} / \mathrm{G}$ & - & PCR-dHPLC/sequencing & $\begin{array}{l}\text { F: acagggttcaccatgtttgcc } \\
\text { R: tttcagcccagtggttgtga }\end{array}$ \\
\hline rs11465804 & Intron 8 & 67475114 & $\mathrm{~T} / \mathrm{G}$ & - & PCR-sequencing & $\begin{array}{l}\text { F: aacaagggaagaaactccgttggg } \\
\text { R: ccacctaagccacttcttacattcag }\end{array}$ \\
\hline rs11209026 & Exon 9 & 67478546 & G/A & Arg381Gln & PCR-dHPLC/sequencing & $\begin{array}{l}\text { F: ccaccctttctcctttgagacctt } \\
\text { R: agctgtgtttggactcagggctta }\end{array}$ \\
\hline rs10889677 & Exon 11 & 67497708 & $\mathrm{C} / \mathrm{A}$ & 3'UTR & PCR-dHPLC/sequencing & $\begin{array}{l}\text { F: ggattgctgggccatatgataagc } \\
\text { R: tgaggcgtccacataatgct }\end{array}$ \\
\hline rs11209032 & Intergenic & 67512680 & G/A & - & PCR-dHPLC/sequencing & $\begin{array}{l}\text { F: ctgaaattgggtaggtactacagtgg } \\
\text { R: aaggcaatccggtggttctt }\end{array}$ \\
\hline rs1495956 & Intergenic & 67526096 & $\mathrm{~T} / \mathrm{C}$ & - & PCR-dHPLC/sequencing & $\begin{array}{l}\text { F: tcccatggctctttccagtt } \\
\mathrm{R}: \text { aactgaggcctagctttgga }\end{array}$ \\
\hline
\end{tabular}

Table 3

Minor allele frequencies for IL23R SNPs between sarcoidosis subjects and controls

\begin{tabular}{|c|c|c|c|c|c|c|c|}
\hline SNP & Allele & $\begin{array}{c}\text { Sarcoidosis } \\
n=91\end{array}$ & $\begin{array}{l}\text { Controls } \\
n=104\end{array}$ & $P$-value & $\begin{array}{l}\text { Corrected } \\
P \text { - value }\end{array}$ & $\begin{array}{l}\text { Odds ratio } \\
(95 \% \mathrm{CI})\end{array}$ & $\begin{array}{c}\text { Caucasian } \\
\text { (CEU) from } \\
\text { HapMap }\end{array}$ \\
\hline rs1004819 & A & 0.280 & 0.274 & 0.892 & 1.000 & $1.031(0.661-1.608)$ & 0.289 \\
\hline rs7517847 & $\mathbf{T}$ & 0.615 & 0.471 & 0.004 & 0.048 & $1.800(1.199-2.690)$ & 0.494 \\
\hline rs7530511 & $\mathrm{T}$ & 0.144 & 0.107 & 0.263 & 1.000 & $1.412(0.770-2.590)$ & 0.139 \\
\hline rs 10489629 & $\mathrm{C}$ & 0.441 & 0.490 & 0.340 & 1.000 & $0.820(0.546-1.232)$ & 0.500 \\
\hline rs2201841 & G & 0.311 & 0.272 & 0.396 & 1.000 & $1.210(0.779-1.879)$ & 0.272 \\
\hline rs11465804 & G & 0.028 & 0.072 & 0.049 & 0.464 & $0.367(0.131-1.032)$ & 0.078 \\
\hline rs11209026 & $\mathbf{A}$ & 0.028 & 0.073 & 0.046 & 0.464 & $0.364(0.130-1.022)$ & 0.072 \\
\hline rs1343151 & A & 0.379 & 0.417 & 0.441 & 1.000 & $0.852(0.567-1.281)$ & 0.378 \\
\hline rs 10889677 & A & 0.300 & 0.260 & 0.376 & 1.000 & $1.222(0.784-1.907)$ & 0.287 \\
\hline rs11209032 & A & 0.294 & 0.337 & 0.357 & 1.000 & $0.823(0.535-1.266)$ & 0.306 \\
\hline rs1495956 & $\mathrm{C}$ & 0.456 & 0.437 & 0.705 & 1.000 & $1.081(0.724-1.614)$ & 0.414 \\
\hline
\end{tabular}

touch-down polymerase chain reaction (PCR) strategy (Table 2). Amplified products were analyzed using denaturing high-performance liquid chromatography (DHPLC) system (WAVE; Transgenomic, Omaha, $\mathrm{NE}$ ) and the resultant chromatograms were compared with those of the wild-type DNA and variant DNA. Direct DNA sequencing was performed to confirm the variants.

\subsection{Statistical analysis}

Allele and genotype frequencies in control and cases were compared by the Chi square test and by the Fisher's exact test when any expected frequency was less than 5 .
The tests were considered statistically significant when the $\mathrm{p}$ values were smaller than 0.05 , and the Holm-Bonferroni correction (Pc) was used to adjust pvalues for multiple tests [13]. The odds ratios (ORs) with $95 \%$ confidence intervals $(\mathrm{CI})$ were also calculated. R statistical language (http://www.r-project.org) was used for computation. Haplotype frequencies and linkage disequilibrium (LD) were estimated and visualized with the Haploview software (available at http: //www.broad.mit.edu/mpg/haploview) [14]. LD plot and $\mathrm{R}^{2}$ value were obtained from the genotype data of the cases and controls and those of the Caucasian population from the HapMap data (available at http://www.hapmap.org). P-values for haplotype asso- 

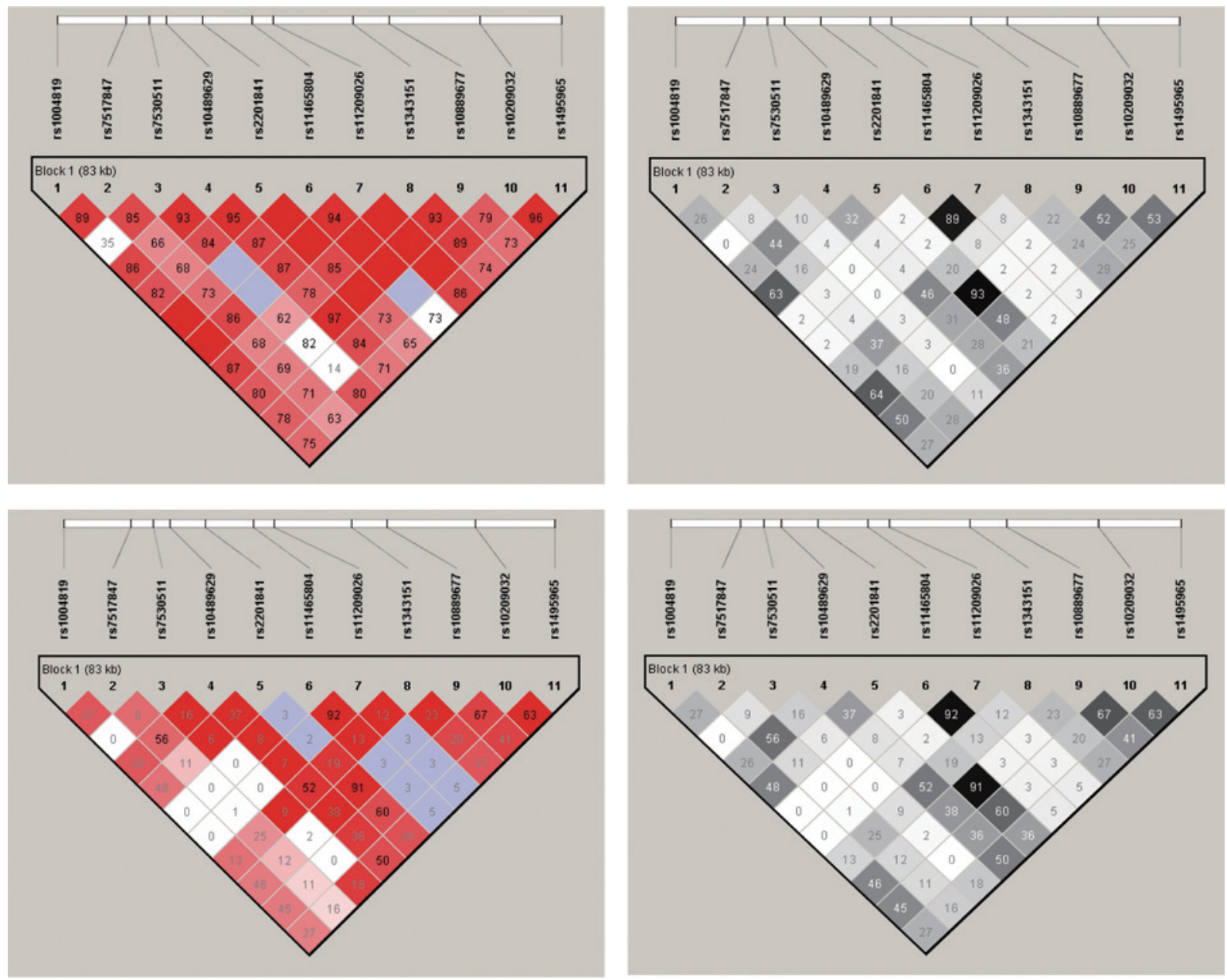

Fig. 1. The structure of linkage disequilibrium between our population (top panels) and Caucasian population from HapMap data (bottom panels) generated by Haploview software. D' (left panels) and $\mathrm{r}^{2}$ value (right panels) between pairs of SNPs were shown in each box and the intensity of the shading is proportional to D' and $\mathrm{r}^{2}$ respectively. Red: strong D', white: low D', blue: high D'/low LOD.

ciation analysis were obtained after 1,000 permutation tests using Haploview software.

\section{Results}

Allele frequencies of 11 IL23R SNPs in sarcoidosis cases and healthy controls are shown in Table 3. Genotypes at all loci were in Hardy-Weinberg equilibrium in both sarcoidosis subjects and controls $(p>0.01)$ except for rs1343151 in control group $(P=0.0004)$. Despite this finding, allele frequencies for all SNPs including rs1343151 in our control population were similar to those of Caucasian population (CEU) from HapMap data.

The $\mathrm{T}$ allele frequency of rs7517847 was significantly higher in patients than controls (cases 0.615 vs. controls $0.471, P=0.004$, OR $=1.800)$. The minor allele frequency (MAF) of SNP rs11209026, previously shown to be protective for Crohn's disease, was decreased in sarcoidosis (patients 0.028 vs. controls $0.073, P=0.046$, OR $=0.364$ ) and MAF of rs11465804, which showed a strong linkage disequilibrium with rs11209026 $\left(r^{2}>0.85\right.$, Fig. 1.), was also decreased in sarcoidosis groups. However, these associations lost their significance when Hom-Bonferroni correction was applied for multiple testing correction (corrected $p>0.05$ ).

Table 4 shows the allele frequencies of 11 IL23R SNPs in two subgroups of sarcoidosis: sarcoidosis with and without uveitis. Minor allele frequencies of rs11209026 and rs11465804 were significantly decreased in the sarcoid uveitis subgroup compared to 
Table 4

Minor allele frequencies for $I L 23 R$ SNPs in control and sarcoidosis subjects with and without uveitis

\begin{tabular}{|c|c|c|c|c|c|c|c|}
\hline SNP & $\begin{array}{c}\text { Allele } \\
\text { Genotype }\end{array}$ & $\begin{array}{c}\text { Sarcoidosis } \\
\text { with uveitis } \\
n=58 \\
{[\mathrm{~A}]}\end{array}$ & $\begin{array}{c}\text { Sarcoidosis } \\
\text { without uveitis } \\
n=31 \\
{[\mathrm{~B}]}\end{array}$ & $\begin{array}{c}\text { Controls } \\
n=104 \\
{[\mathrm{C}]}\end{array}$ & $\begin{array}{c}P \text {-value } \\
\text { OR }(95 \% \mathrm{CI}) \\
{[\text { A vs. C] }}\end{array}$ & $\begin{array}{c}P \text {-value } \\
\text { OR }(95 \% \text { CI }) \\
{[\text { B vs. C] }}\end{array}$ & $\begin{array}{c}P \text {-value } \\
\text { OR }(95 \% \mathrm{CI}) \\
{[\text { A vs. B] }}\end{array}$ \\
\hline rs 1004819 & $\mathrm{~A}$ & 0.259 & 0.318 & 0.274 & $\begin{array}{c}0.865 \\
0.924(0.052-1.547)\end{array}$ & $\begin{array}{c}0.592 \\
1.236(0.678-2.255)\end{array}$ & $\begin{array}{c}0.491 \\
0.748(0.385-1.452)\end{array}$ \\
\hline rs7517847 & $\mathbf{T}$ & 0.569 & 0.697 & 0.471 & $\begin{array}{c}0.116 \\
0.675(0.427-1.066)\end{array}$ & $\begin{array}{c}0.002 \\
0.387(0.214-0.700)\end{array}$ & $\begin{array}{c}0.122 \\
1.742(0.918-3.307)\end{array}$ \\
\hline rs7530511 & $\mathbf{T}$ & 0.105 & 0.212 & 0.107 & $\begin{array}{c}0.883 \\
0.984(0.468-2.070)\end{array}$ & $\begin{array}{c}0.046 \\
2.252(1.077-4.707)\end{array}$ & $\begin{array}{c}0.081 \\
0.437(0.189-1.013)\end{array}$ \\
\hline rs10489629 & $\mathrm{C}$ & 0.482 & 0.367 & 0.490 & $\begin{array}{c}0.978 \\
0.966(0.609-1.534)\end{array}$ & $0.602(0.333-1.087)$ & $\begin{array}{c}0.199 \\
1.606(0.843-3.060)\end{array}$ \\
\hline rs2201841 & G & 0.289 & 0.348 & 0.272 & $\begin{array}{c}0.836 \\
1.091(0.657-1.814)\end{array}$ & $\begin{array}{c}0.299 \\
1.433(0.793-2.590)\end{array}$ & $\begin{array}{c}0.511 \\
0.762(0.398-1.456)\end{array}$ \\
\hline rs11465804 & $\mathbf{G}$ & 0.009 & 0.061 & 0.072 & $\begin{array}{c}0.013 \\
0.114(0.015-0.874)\end{array}$ & $\begin{array}{c}1.000 \\
0.830(0.266-2.594)\end{array}$ & $\begin{array}{c}0.061 \\
0.137(0.015-1.254)\end{array}$ \\
\hline rs11209026 & $\mathbf{A}$ & 0.018 & 0.045 & 0.073 & $\begin{array}{c}0.038 \\
0.227(0.051-1.013)\end{array}$ & $\begin{array}{c}0.576 \\
0.606(0.170-2.163)\end{array}$ & $\begin{array}{c}0.358 \\
0.375(0.061-2.304)\end{array}$ \\
\hline rs 1343151 & A & 0.422 & 0.303 & 0.417 & $\begin{array}{c}0.975 \\
1.021(0.644-1.618)\end{array}$ & $\begin{array}{c}0.130 \\
0.607(0.335-1.098)\end{array}$ & $\begin{array}{c}0.151 \\
1.682(0.886-3.194)\end{array}$ \\
\hline rs10889677 & A & 0.281 & 0.333 & 0.260 & $\begin{array}{c}0.782 \\
1.113(0.666-1.859)\end{array}$ & $\begin{array}{c}0.314 \\
1.426(0.784-2.594)\end{array}$ & $\begin{array}{c}0.566 \\
0.781(0.406-1.502)\end{array}$ \\
\hline rs11209032 & A & 0.281 & 0.318 & 0.337 & $\begin{array}{c}0.366 \\
0.764(0.463-1.259)\end{array}$ & $\begin{array}{c}0.900 \\
0.913(0.505-1.652)\end{array}$ & $\begin{array}{c}0.717 \\
0.836(0.432-1.618)\end{array}$ \\
\hline rs 1495956 & $\mathrm{C}$ & 0.414 & 0.530 & 0.437 & $\begin{array}{c}0.776 \\
0.910(0.574-1.442)\end{array}$ & $\begin{array}{c}0.237 \\
1.455(0.834-2.538)\end{array}$ & $\begin{array}{c}0.173 \\
0.625(0.340-1.149)\end{array}$ \\
\hline
\end{tabular}

Table 5

Estimated haplotype frequencies between sarcoidosis and control subjects

\begin{tabular}{cccccc}
\hline Haplotype & Sarcoidosis+control & Sarcoidosis & Control & $P$-value & $\begin{array}{c}\text { Caucasian (CEU) } \\
\text { from HapMap }\end{array}$ \\
\hline GGCCATGACGT & 0.248 & 0.230 & 0.263 & 0.4553 & 0.224 \\
ATCTGTGGAAC & 0.208 & 0.231 & 0.190 & 0.3210 & 0.188 \\
GTTTATGGCGC & $\mathbf{0 . 0 6 5}$ & $\mathbf{0 . 1 0 1}$ & $\mathbf{0 . 0 3 4}$ & $\mathbf{0 . 0 0 7 8}$ & $\mathbf{0 . 0 7 1}$ \\
GTCTATGGCGT & 0.063 & 0.087 & 0.041 & 0.0644 & 0.076 \\
GGCCATGGCGT & 0.056 & 0.038 & 0.071 & 0.1628 & 0.118 \\
GGCCAGAACGT & 0.040 & 0.022 & 0.055 & 0.0961 & 0.055 \\
GTCCATGACGT & 0.030 & 0.047 & 0.015 & 0.0616 & 0.022 \\
GTCTATGGCAC & 0.024 & 0.011 & 0.036 & 0.1220 & 0.006 \\
GTCCATGGCGT & 0.021 & 0.024 & 0.019 & 0.7289 & 0.018 \\
ATCTGTGGAGT & 0.018 & 0.030 & 0.008 & 0.1135 & 0.017 \\
GGCCATGACGC & 0.017 & 0.029 & 0.007 & 0.0900 & 0.017 \\
GGCTGTGGAAC & 0.016 & 0.014 & 0.019 & 0.6822 & 0.045 \\
GTCTATGGCGC & 0.015 & 0.004 & 0.024 & 0.1141 & \\
GGCTGTGGAGT & 0.013 & 0.021 & 0.006 & 0.1794 & \\
GGTTATGGCGC & 0.012 & 0.010 & 0.014 & 0.7140 & 0.012 \\
GGCTATGACGT & 0.011 & 0.001 & 0.020 & 0.0707 & \\
ATTTATGGCAC & 0.011 & 0.006 & 0.015 & 0.3723 & 0.027 \\
GGCCATGGCAC & 0.010 & 0.012 & 0.009 & 0.8046 & \\
\hline
\end{tabular}

* Haplotypes with estimated frequencies $>0.01$ are shown.

controls (rs11209026 $P=0.038$, rs11465804 $P=$ 0.013).

Estimated haplotypes whose frequencies were higher than 0.01 were obtained by the Haploview program (Table 5). The frequency of one haplotype GTTTATGGCGC showed significant differences between cases and controls ( 0.101 vs. $0.034, P=0.0078)$, which still remained significant $(P=0.023)$ after being corrected by 1,000 random permutation tests for haplotypes. This haplotype included three alleles of three SNP [rs7517847 (T), rs11465804 (T), and rs11209026 (G)] showing significant differences between cases and controls. However, there was no significant difference in frequency of this haplotype between sarcoidosis 
Table 6

Reported minor allele frequencies (MAF) of IL23R rs11209026 in case control association studies

\begin{tabular}{clccccc}
\hline Disease* & Population & $\begin{array}{c}\text { Case } \\
\text { MAF }(\%)\end{array}$ & $\begin{array}{c}\text { Control } \\
\text { MAF }(\%)\end{array}$ & P-value & OR & References \\
\hline CD & Non-Jewish & 1.9 & 7 & $5.05 \mathrm{E}-09$ & 0.26 & {$[6]$} \\
CD & Jewish & 3.3 & 7 & $7.95 \mathrm{E}-04$ & 0.45 & {$[6]$} \\
CD & Spanish white & 2 & 7 & 0.001 & 0.3 & {$[9]$} \\
IBD & Nethelands & 1.2 & 6.5 & $5.30 \mathrm{E}-08$ & 0.19 & {$[19]$} \\
CD & UK Caucasian & 2.6 & 5.9 & $6.58 \mathrm{E}-06$ & 0.43 & {$[20]$} \\
UC & UK Caucasian & 3.8 & 5.9 & 0.0081 & 0.63 & {$[20]$} \\
CD & German & 3 & 6.8 & $8.04 \mathrm{E}-08$ & 0.43 & {$[21]$} \\
UC & German & 4.9 & 6.8 & 0.036 & 0.7 & {$[21]$} \\
CD & Italian & 2.1 & 5.9 & 0.0067 & 0.33 & {$[22]$} \\
CD & New Zealand & 4 & 7 & 0.0026 & 0.54 & {$[23]$} \\
UC & New Zealand & 4 & 7 & 0.037 & 0.66 & {$[23]$} \\
CD & UK Caucasian & 2.5 & 6.2 & $1.10 \mathrm{E}-12$ & 0.38 & {$[24]$} \\
Psoriasis & UK Caucasian & 3.6 & 7 & 0.00014 & 0.49 & {$[25]$} \\
Psoriasis & Caucasian & $3.5 \sim 5.1$ & $6.0 \sim 7.7$ & $1.89 \mathrm{E}-04$ & 0.63 & {$[12]$} \\
AS & Spanish & 3 & 7 & 0.001 & 0.46 & {$[18]$} \\
AS & UK Caucasian & 4 & 6 & $4.00 \mathrm{E}-06$ & 0.63 & {$[26]$} \\
& & & & & & \\
Sarcoidosis & 91.2\% Caucasian & $\mathbf{2 . 8}$ & $\mathbf{7 . 3}$ & $\mathbf{0 . 0 4 6}$ & $\mathbf{0 . 3 6}$ & This study \\
\hline
\end{tabular}

*Abbreviations: CD, Crohn's disease; UC, ulcerative colitis; IBD, inflammatory bowel disease; AS ankylosing spondylitis.

uveitis and control group (0.071 vs. $0.034, P=0.132$ by Haploview program).

Figure 1 shows the linkage disequilibrium among 11 SNPs. The SNP pairs, rs11465804 with rs11209026, and rs2201841 with rs10889677, showed strong linkage disequilibrium $\left(r^{2}>0.85\right)$ in our population. The pattern of linkage disequilibrium $\left(\mathrm{r}^{2}\right)$ in our population was very similar to that of a Caucasian population (CEU) from HapMap data.

\section{Discussion}

In this study three IL23R SNPs, rs7517847, rs11465804, and rs11209026 (c.1142G>A, p.Arg381 Gln) were nominally significant but did not withstand correction for multiple testing and two of these SNPs, rs11465804 and rs11209026, were associated with the sarcoid uveitis subgroup. It is noteworthy that the coding SNP rs11209026 (p.Arg381Gln), previously identified to be protective for Crohn's disease, was also decreased in sarcoidosis subjects compared to controls and the difference of allele frequencies and odds ratio of the SNP between the two groups in this study were similar to those of other reported studies showing significant associations with several autoimmune diseases (Table 6). These results suggest the possibility of the SNP rs11209026 to show more significant association with sarcoidosis when analyzed in a larger population, whereas our data, with relatively small study groups, show only a weak association of the SNP with sarcoidosis. Recently, the SNP rs11209026 in the IL23R gene was reported to be associated with German chronic sarcoidosis [15]. Therefore, our study could be a replication to validate the association of IL23R gene with sarcoidosis. We cannot exclude the possibility that this association is due not to sarcoidosis but due to uveitis in our study because rs11209026 showed an association with sarcoid uveitis subgroup only, and not with the sarcoidosis without uveitis subgroup. Further studies will be needed for confirmation.

IL23R SNP rs11209026 has been reported to be associated with IBD, psoriasis, and ankylosing spondylitis, but not with Graves' disease and systemic lupus erythematosus. Multiple sclerosis and rheumatoid arthritis showed different results between studies [7]. This means $I L 23 R$ may be a common susceptible gene only to IBD, psoriasis, and AS, but not to the latter diseases. There have been speculations that $I L 23 R$ may play a more important role in regulating local rather than systemic inflammation [16,17]. Since all of the above diseases are multifactorial in etiology, gene to gene or gene to environmental interactions may act as another cause of the difference. Also, the degree and the variety of associated SNPs may differ among various diseases.

The biological impact and functionality of IL23R polymorphism is currently unknown. The site of Arg381Gln polymorphism is located in the initial portion of the IL23R intracytoplasmic region, very close to the first putative tyrosine phosphorylation site at po- 
sition 399 [10]. By changing the Arg to Gln at position 381 , the interaction between IL23R and its associated Jak-2 kinase may be modified. Lowering of the IL23 signaling pathway by genetic variation of its receptor may protect individuals from severe inflammatory response to environmental factors [18].

In conclusion, this study indicates the association of $I L 23 R$ polymorphism with sarcoidosis, especially with sarcoid uveitis. $I L 23 R$ may be a common susceptibility gene shared by several autoimmune disorders including inflammatory bowel disease, psoriasis, and ankylosing spondylitis and sarcoid uveitis.

\subsection{Support statement}

This work was supported by R01 EY013139 and EY0105712 from the National Institutes of Health (NIH; Bethesda, MD, USA); and by Research to Prevent Blindness (New York, NY, USA) awards to the Casey Eye Institute, JRS, JTR, and TMM.

\section{Acknowledgements}

We would like to acknowledge Jinnell A. Lewis for important contributions related to subject recruitment and medical record procurement.

\section{References}

[1] Statement on sarcoidosis. Joint Statement of the American Thoracic Society (ATS), the European Respiratory Society (ERS) and the World Association of Sarcoidosis and Other Granulomatous Disorders (WASOG) adopted by the ATS Board of Directors and by the ERS Executive Committee, February 1999, Am J Respir Crit Care Med 160 (1999), 736755.

[2] B.A. Rybicki, M.C. Iannuzzi, M.M. Frederick, B.W. Thompson, M.D. Rossman, E.A. Bresnitz, M.L. Terrin, D.R. Moller, J. Barnard, R.P. Baughman, L. DePalo, G. Hunninghake, C. Johns, M.A. Judson, G.L. Knatterud, G. McLennan, L.S. Newman, D.L. Rabin, C. Rose, A.S. Teirstein, S.E. Weinberger, H. Yeager and R. Cherniack, Familial aggregation of sarcoidosis. A case-control etiologic study of sarcoidosis (ACCESS), Am J Respir Crit Care Med 164 (2001), 2085-2091.

[3] M.C. Iannuzzi and B.A. Rybicki, Genetics of sarcoidosis: candidate genes and genome scans, Proc Am Thorac Soc 4 (2007), $108-116$.

[4] G. Smith, I. Brownell, M. Sanchez and S. Prystowsky, Advances in the genetics of sarcoidosis, Clin Genet 73 (2008), $401-412$.

[5] J. Grunewald, Genetics of sarcoidosis, Curr Opin Pulm Med 14 (2008), 434-439.
[6] R.H. Duerr, K.D. Taylor, S.R. Brant, J.D. Rioux, M.S. Silverberg, M.J. Daly, A.H. Steinhart, C. Abraham, M. Regueiro, A. Griffiths, T. Dassopoulos, A. Bitton, H. Yang, S. Targan, L.W. Datta, E.O. Kistner, L.P. Schumm, A.T. Lee, P.K. Gregersen, M.M. Barmada, J.I. Rotter, D.L. Nicolae and J.H. Cho, A genome-wide association study identifies IL23R as an inflammatory bowel disease gene, Science 314 (2006), 1461-1463.

[7] E. Safrany and B. Melegh, Functional variants of the interleukin-23 receptor gene in non-gastrointestinal autoimmune diseases, Curr Med Chem 16 (2009), 3766-3774.

[8] A.R. de Leon, J.P. de la Serna, J.L. Santiago, C. Sevilla, M. Fernandez-Arquero, E.G. de la Concha, C. Nunez, E. Urcelay and A.G. Vigo, Association between idiopathic achalasia and IL23R gene, Neurogastroenterol Motil 22 (2010), 734-738.

[9] J. Oliver, B. Rueda, M.A. Lopez-Nevot, M. Gomez-Garcia and J. Martin, Replication of an association between IL23R gene polymorphism with inflammatory bowel disease, Clin Gastroenterol Hepatol 5 (2007), 977-981.

[10] C. Parham, M. Chirica, J. Timans, E. Vaisberg, M. Travis, J. Cheung, S. Pflanz, R. Zhang, K.P. Singh, F. Vega, W. To, J. Wagner, A.M. O’Farrell, T. McClanahan, S. Zurawski, C. Hannum, D. Gorman, D.M. Rennick, R.A. Kastelein, R. de Waal Malefyt and K.W. Moore, A receptor for the heterodimeric cytokine IL-23 is composed of IL-12Rbeta1 and a novel cytokine receptor subunit, IL-23R, J Immunol 168 (2002), 5699-5708.

[11] K. Kikly, L. Liu, S. Na and J.D. Sedgwick, The IL-23/Th(17) axis: therapeutic targets for autoimmune inflammation, Curr Opin Immunol 18 (2006), 670-675.

[12] M. Cargill, S.J. Schrodi, M. Chang, V.E. Garcia, R. Brandon, K.P. Callis, N. Matsunami, K.G. Ardlie, D. Civello, J.J. Catanese, D.U. Leong, J.M. Panko, L.B. McAllister, C.B. Hansen, J. Papenfuss, S.M. Prescott, T.J. White, M.F. Leppert, G.G. Krueger and A.B. Begovich, A large-scale genetic association study confirms IL12B and leads to the identification of IL23R as psoriasis-risk genes, Am J Hum Genet 80 (2007), 273-290.

[13] S. Holm, A simple sequentially rejective multiple test procedure, Scand J Statistics 6 (1979), 65-70.

[14] J.C. Barrett, B. Fry, J. Maller and M.J. Daly, Haploview: analysis and visualization of LD and haplotype maps, Bioinformatics 21 (2005), 263-265.

[15] A. Fischer, M. Nothnagel, A. Franke, G. Jacobs, H.R. Saadati, K.I. Gaede, P. Rosenstiel, M. Schurmann, J. MullerQuernheim, S. Schreiber and S. Hofmann, Association of IBD Risk Loci with Sarcoidosis and its Acute and Chronic Subphenotypes, Eur Respir J (2010) [Epub ahead of print].

[16] E. Sanchez, B. Rueda, J.L. Callejas, J.M. Sabio, N. OrtegoCenteno, J. Jimenez-Alonso, M.A. Lopez-Nevot and J. Martin, Analysis of interleukin-23 receptor (IL23R) gene polymorphisms in systemic lupus erythematosus, Tissue Antigens 70 (2007), 233-237.

[17] H.H. Uhlig, B.S. McKenzie, S. Hue, C. Thompson, B. JoyceShaikh, R. Stepankova, N. Robinson, S. Buonocore, H. Tlaskalova-Hogenova, D.J. Cua and F. Powrie, Differential activity of IL-12 and IL-23 in mucosal and systemic innate immune pathology, Immunity 25 (2006), 309-318.

[18] B. Rueda, G. Orozco, E. Raya, J.L. Fernandez-Sueiro, J. Mulero, F.J. Blanco, C. Vilches, M.A. Gonzalez-Gay and J. Martin, The IL23R Arg381Gln non-synonymous polymorphism confers susceptibility to ankylosing spondylitis, Ann Rheum Dis 67 (2008), 1451-1454.

[19] R.K. Weersma, A. Zhernakova, I.M. Nolte, C. Lefebvre, J.D. Rioux, F. Mulder, H.M. van Dullemen, J.H. Kleibeuker, C. Wijmenga and G. Dijkstra, ATG16L1 and IL23R are asso- 
ciated with inflammatory bowel diseases but not with celiac disease in the Netherlands, Am J Gastroenterol 103 (2008), 621-627.

[20] J.R. Cummings, T. Ahmad, A. Geremia, J. Beckly, R. Cooney, L. Hancock, S. Pathan, C. Guo, L.R. Cardon and D.P. Jewell, Contribution of the novel inflammatory bowel disease gene IL23R to disease susceptibility and phenotype, Inflamm Bowel Dis 13 (2007), 1063-1068.

[21] J. Glas, J. Seiderer, M. Wetzke, A. Konrad, H.P. Torok, S. Schmechel, L. Tonenchi, C. Grassl, J. Dambacher, S. Pfennig, K. Maier, T. Griga, W. Klein, J.T. Epplen, U. Schiemann, C. Folwaczny, P. Lohse, B. Goke, T. Ochsenkuhn, B. Muller-Myhsok, M. Folwaczny, T. Mussack and S. Brand, rs 1004819 is the main disease-associated IL23R variant in German Crohn's disease patients: combined analysis of IL23R, CARD15, and OCTN1/2 variants, PLOS ONE 2 (2007), e819.

[22] P. Borgiani, C. Perricone, C. Ciccacci, S. Romano, G. Novelli, L. Biancone, C. Petruzziello and F. Pallone, Interleukin-23R Arg381Gln is associated with susceptibility to Crohn's disease but not with phenotype in an Italian population, Gastroenterology 133 (2007), 1049-1051; author reply 1051-1042.

[23] R.L. Roberts, R.B. Gearry, J.E. Hollis-Moffatt, A.L. Miller, J. Reid, V. Abkevich, K.M. Timms, A. Gutin, J.S. Lanchbury, T.R. Merriman, M.L. Barclay and M.A. Kennedy, IL23R R381Q and ATG16L1 T300A are strongly associated with Crohn's disease in a study of New Zealand Caucasians with inflammatory bowel disease, Am J Gastroenterol 102 (2007), 2754-2761.

[24] M. Tremelling, F. Cummings, S.A. Fisher, J. Mansfield, R. Gwilliam, A. Keniry, E.R. Nimmo, H. Drummond, C.M. Onnie, N.J. Prescott, J. Sanderson, F. Bredin, C. Berzuini, A. Forbes, C.M. Lewis, L. Cardon, P. Deloukas, D. Jewell, C.G. Mathew, M. Parkes and J. Satsangi, IL23R variation determines susceptibility but not disease phenotype in inflammatory bowel disease, Gastroenterology 132 (2007), 1657-1664.

[25] F. Capon, P. Di Meglio, J. Szaub, N.J. Prescott, C. Dunster, L. Baumber, K. Timms, A. Gutin, V. Abkevic, A.D. Burden, J. Lanchbury, J.N. Barker, R.C. Trembath and F.O. Nestle, Sequence variants in the genes for the interleukin-23 receptor (IL23R) and its ligand (IL12B) confer protection against psoriasis, Hum Genet 122 (2007), 201-206.

[26] P.R. Burton, D.G. Clayton, L.R. Cardon, N. Craddock, P. Deloukas, A. Duncanson, D.P. Kwiatkowski, M.I. McCarthy, W.H. Ouwehand, N.J. Samani, J.A. Todd, P. Donnelly, J.C.
Barrett, D. Davison, D. Easton, D.M. Evans, H.T. Leung, J.L. Marchini, A.P. Morris, C.C. Spencer, M.D. Tobin, A.P. Attwood, J.P. Boorman, B. Cant, U. Everson, J.M. Hussey, J.D. Jolley, A.S. Knight, K. Koch, E. Meech, S. Nutland, C.V. Prowse, H.E. Stevens, N.C. Taylor, G.R. Walters, N.M. Walker, N.A. Watkins, T. Winzer, R.W. Jones, W.L. McArdle, S.M. Ring, D.P. Strachan, M. Pembrey, G. Breen, D. St Clair, S. Caesar, K. Gordon-Smith, L. Jones, C. Fraser, E.K. Green, D. Grozeva, M.L. Hamshere, P.A. Holmans, I.R. Jones, G. Kirov, V. Moskivina, I. Nikolov, M.C. O’Donovan, M.J. Owen, D.A. Collier, A. Elkin, A. Farmer, R. Williamson, P. McGuffin, A.H. Young, I.N. Ferrier, S.G. Ball, A.J. Balmforth, J.H. Barrett, T.D. Bishop, M.M. Iles, A. Maqbool, N. Yuldasheva, A.S. Hall, P.S. Braund, R.J. Dixon, M. Mangino, S. Stevens, J.R. Thompson, F. Bredin, M. Tremelling, M. Parkes, H. Drummond, C.W. Lees, E.R. Nimmo, J. Satsangi, S.A. Fisher, A. Forbes, C.M. Lewis, C.M. Onnie, N.J. Prescott, J. Sanderson, C.G. Matthew, J. Barbour, M.K. Mohiuddin, C.E. Todhunter, J.C. Mansfield, T. Ahmad, F.R. Cummings, D.P. Jewell, J. Webster, M.J. Brown, M.G. Lathrop, J. Connell, A. Dominiczak, C.A. Marcano, B. Burke, R. Dobson, J. Gungadoo, K.L. Lee, P.B. Munroe, S.J. Newhouse, A. Onipinla, C. Wallace, M. Xue, M. Caulfield, M. Farrall, A. Barton, I.N. Bruce, H. Donovan, S. Eyre, P.D. Gilbert, S.L. Hilder, A.M. Hinks, S.L. John, C. Potter, A.J. Silman, D.P. Symmons, W. Thomson, J. Worthington, D.B. Dunger, B. Widmer, T.M. Frayling, R.M. Freathy, H. Lango, J.R. Perry, B.M. Shields, M.N. Weedon, A.T. Hattersley, G.A. Hitman, M. Walker, K.S. Elliott, C.J. Groves, C.M. Lindgren, N.W. Rayner, N.J. Timpson, E. Zeggini, M. Newport, G. Sirugo, E. Lyons, F. Vannberg, A.V. Hill, L.A. Bradbury, C. Farrar, J.J. Pointon, P. Wordsworth, M.A. Brown, J.A. Franklyn, J.M. Heward, M.J. Simmonds, S.C. Gough, S. Seal, M.R. Stratton, N. Rahman, M. Ban, A. Goris, S.J. Sawcer, A. Compston, D. Conway, M. Jallow, K.A. Rockett, S.J. Bumpstead, A. Chaney, K. Downes, M.J. Ghori, R. Gwilliam, S.E. Hunt, M. Inouye, A. Keniry, E. King, R. McGinnis, S. Potter, R. Ravindrarajah, P. Whittaker, C. Widden, D. Withers, N.J. Cardin, T. Ferreira, J. Pereira-Gale, I.B. Hallgrimsdo'ttir, B.N. Howie, Z. Su, Y.Y. Teo, D. Vukcevic, D. Bentley, S.L. Mitchell, P.R. Newby, O.J. Brand, J. Carr-Smith, S.H. Pearce, J.D. Reveille, X. Zhou, A.M. Sims, A. Dowling, J. Taylor, T. Doan, J.C. Davis, L. Savage, M.M. Ward, T.L. Learch, M.H. Weisman and M. Brown, Association scan of 14,500 nonsynonymous SNPs in four diseases identifies autoimmunity variants, Nat Genet 39 (2007), 1329-1337. 


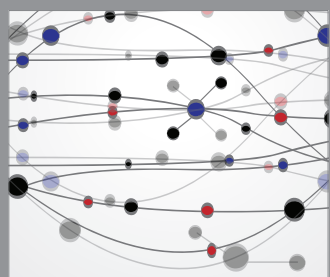

The Scientific World Journal
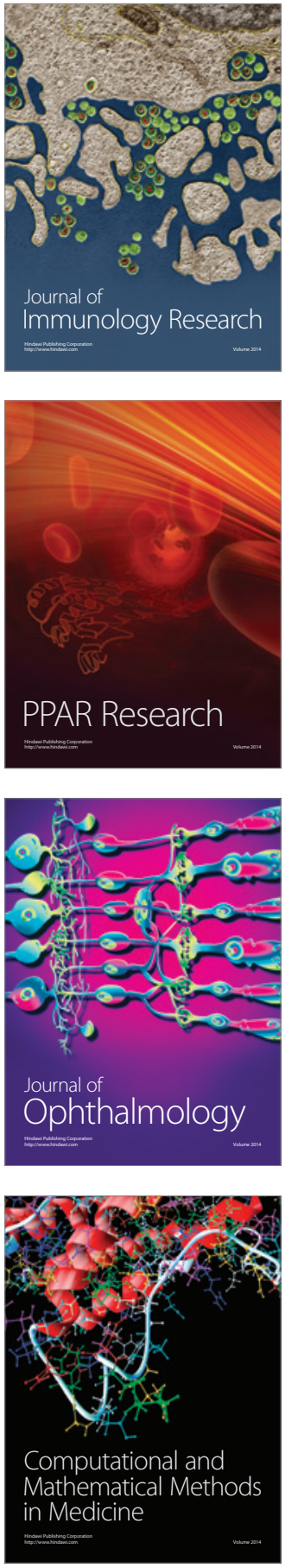

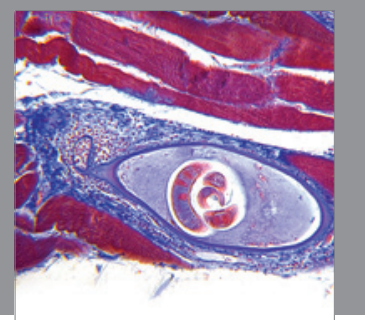

Gastroenterology

Research and Practice
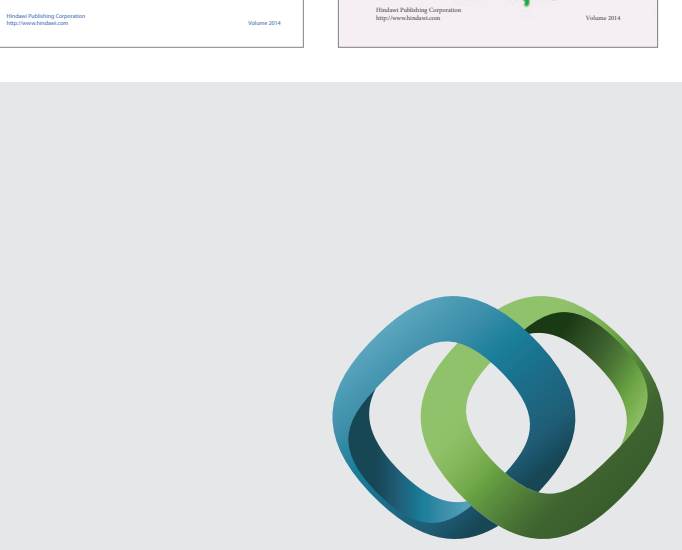

\section{Hindawi}

Submit your manuscripts at

http://www.hindawi.com
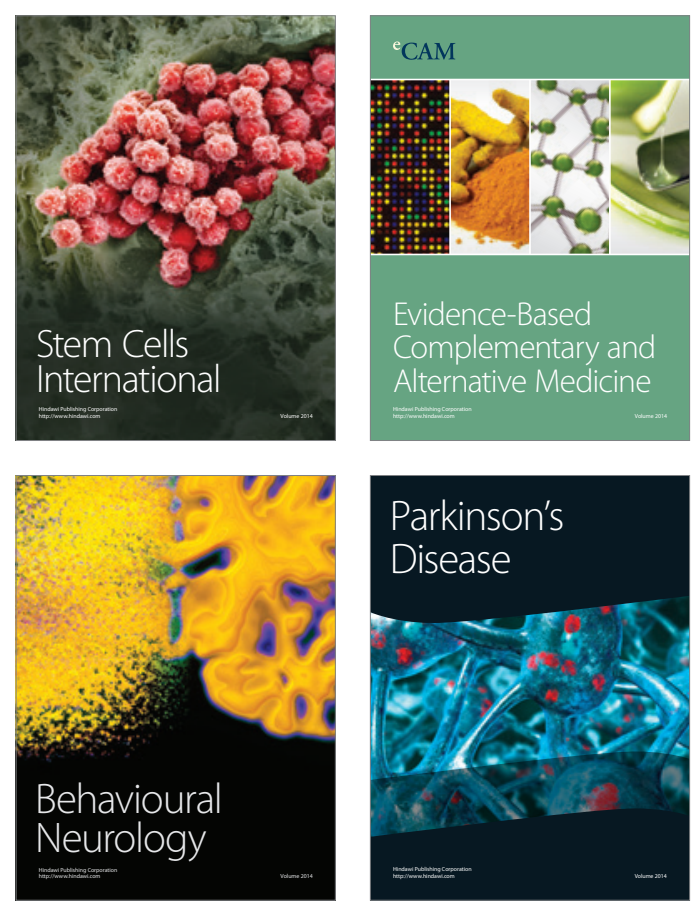

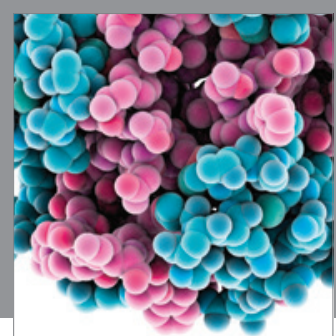

Journal of
Diabetes Research

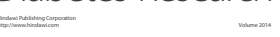

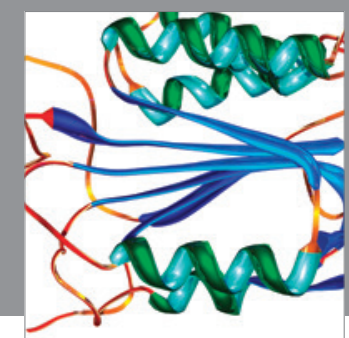

Disease Markers
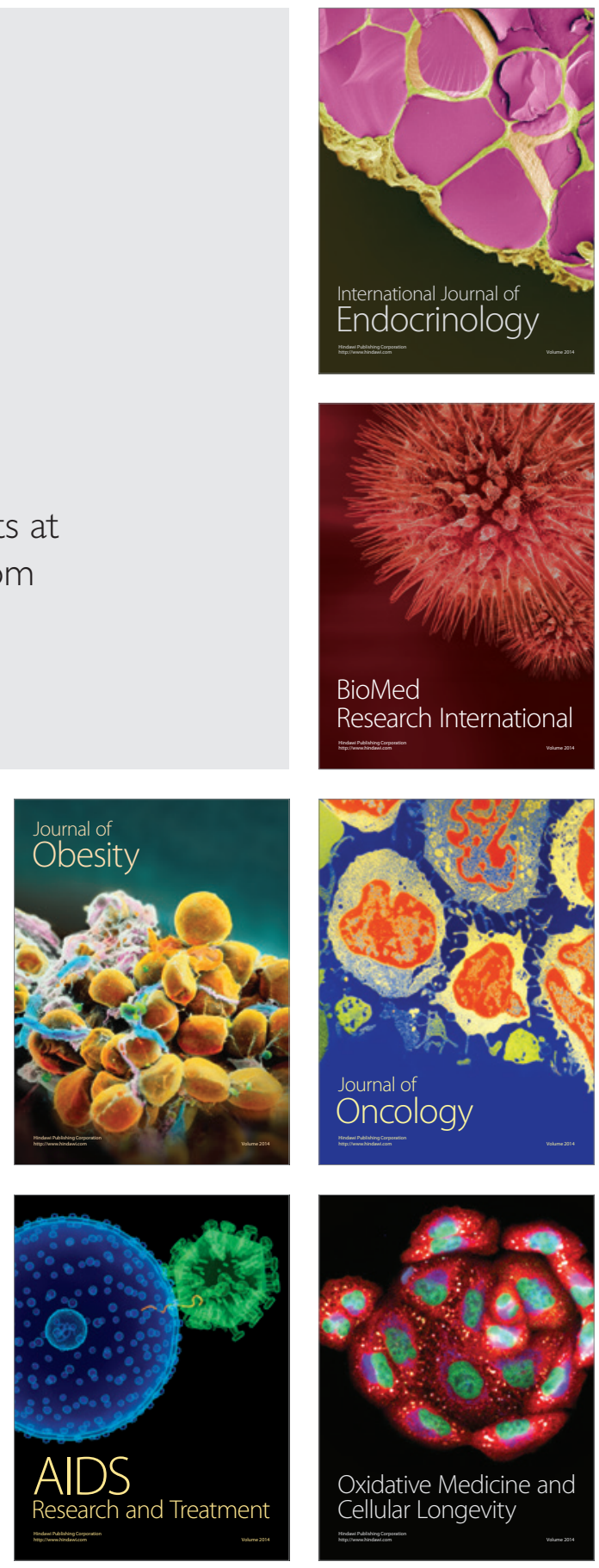